\title{
Editorial: Taking The Computer Games Journal to the next level
}

\author{
A farewell message from the editors-in-chief
}

According 